\title{
Structural validity and reliability of the healthcare professionals' economic reasoning questionnaire
}

\author{
Mira H. Vuković ${ }^{1}$, Mihajlo B. Jakovljević ${ }^{2}$ \\ ${ }^{1}$ Education Center, General Hospital Valjevo, Valjevo, Serbia \\ ${ }^{2}$ Health Economics and Pharmacoeconomics, The Faculty of Medical Sciences, \\ University of Kragujevac, Serbia
}

\section{SUMMARY}

Introduction: The structure of healthcare professionals' economic reasoning (HPER) is still unknown.

The aim: The structural validity and the reliability of the HPER questionnaire were evaluated.

Methods: The psychometric study about evaluation of the HPER factors was conducted. The healthcare professionals (physicians, dentists, pharmacists) that are employed in healthcare state sector of Republic of Serbia were interviewed. The HPER Questionnaire contained 29 preliminary items. Its structure was evaluated by Principal Component Analisis for categorial and ordinal data.

Results: The 9 items that defined seven HPER factors were extracted: (1) the negligence of the cost of quality by the administration and financier; (2) the consideration of the market price and healthcare benefit; (3) market orientation considering patient's requests; (4) the recognition of inadequate resource alocations by non-medical administrative authority; (5) the attitude about redirecting the profit from state to private healthcare sector; $(6)$ the recognition of the unjustified spending by the healthcare professionals and (7) the relationship physician/patient.

Conclusion: The HPER-9 Questionnaire has high structural validity and reliability in the HPER measurement.

Keywords: economic reasoning, healthcare professionals, healthcare institutions, psychometric analysis

\section{INTRODUCTION}

Technical and technological promotions in the healthcare system of the highly developed countries led to the increase of different cost categories in their healthcare economy [1-4]. State institutions that are responsible for conducting the healthcare economic reforms, reached the consensus that the healthcare professionals medical decision is evidence based practice, that is the key factor that must be monitored and controlled in order to restrain further cost increase, but to also create the space for further promotion of the citizen healthcare [5]. It is important to highlight that making the medical decision in accordance with the evidence based practice is only a segment of the healthcare professionals' econom- 
ic reasoning (HPER). From the psycometric, sociometric and econometric point of view, the healtcare professional's reasoning needs to accept the assumption of this problem's multidimensionality [5-8].

On the other hand, the whole series of the assumed components of the HPER is known, among which there are some that point out: the experience of personal responsibility in the cost control, enthusiasm in creating the strategy to reduce the costs [6], observing professional role in the cost constrain, observing the obstacles and practical consequences of the concerning about the costs [7], awareness and attitude about providing healthcare [8].

However, the assumed psycometric factors of the HPER are practically not competent to be evaluated in some extreme situations, such as the extreme social-economic poverty that is followed by the lack of human resources in healthcare system [9] or some other disorders that are presented by low structural and some other healthcare quality indicator value [10].

Also, it is noticed that the psychometric factors of the economic reasoning actually remained on the assumed level instead of being developed to the level of the evaluated HPER structure. In other words, the assumed structure of a few measurement instruments of the HPER, was not analyzed by psychometric methods that can proof, expand, accept or reject these beforehand assumed structures [5-8]. On the other hand, the clarification of the changes in the level of the potential HPER factors is very important when planning, conducting and evaluating the outcomes od healthcare-economic and/or healtcare-political reforms $[8,11,12]$.

Having the above mentioned in mind, we considered important to psychometrically analyze factors or dimensions of the HPER.

\section{THE AIM}

This study's goal is to evaluate the structural validity and reliability of the healthcare professional's economic reasoning questionnaire with defining it's latent structure.

\section{METHODS}

\section{Study design}

The study was conducted as an observational study that covered a cohort of interviewed healthcare professionals that are employed in healthcare institutions of the Republic of Serbia in time period from 2010 - 2013 year.

\section{Population}

The following was included in the study:

1. healthcare professionals (phisicians, dentists or pharmacists);

2. employees of the institutions of the primary, secondary or terciery healthcare or the employees in pharmacy institutuions and

3. that have willingly accepted to take part in the interviewing according to the HPER Questionnaire.

The following was excluded from the study:

1. the interviewed healthcare professionals that lack more than $10 \%$ of data according to the HPER Questionnaire or

2. the interviewed healthcare professionals that have more than $10 \%$ of multiple rated answers according to the HPER Questionnaire.

\section{The measurement instrument}

As a base for the approximate definition of the individual 29 items according to the HPER Questionnaire that was applied in our study, [13] we used the HPER Questionnaire (Skootsky AS at al,1999) version that contained 11 items [8]. Modalities of the offered answers according to the HPER-29 were: I quite agree, I agree, I don't have opinion, I don't agree and I don't agree at all. The offered ordinal anwer modalities will be expressed numerically according to the upward Likert's scale from 0-4, corresponding the level of the agreement with every item or assertion, so that the minimal level of agreement (I don't agree at all) is rated as a 0 , whereas the maximum level of agreement ( $I$ quite agree) is rated as a 4 . The interviewing of the healthcare professionals was conducted in their spare time lasting 10 minutes.

\section{Statistical methods}

The description of the measurement variables was done by showing the mean as a measure of the central tendention of the set of data, while the variation of the set of data was shown by the standard deviation. The structural validity and reliability with defining the latent structure of HPER-19 and data reduction, was evaluated by Principal component analysis for categorical and ordinal data (CATAPCA). In the process of the elimination of the items and extraction of the dimensions (latent components) in CATAPCA model, it was accepted 
Table 1. CATAPCA model - Factors loading per items and dimensions of the HPER-9 Questionnaire

D1 - The negligence of the cost of quality by the administration and financier

D2 - The consideration of the market price and healthcare benefit

D3 - Market orientation considering patient's requests

D4 - The recognition of inadequate resource alocations by non-medical administrative authority

D5 - The attitude about redirecting the profit from state to private healthcare sector D6 - The recognition of the unjustified spending by the healthcare professionals

D7 - The relationship

physician/patient

* The item recoding is done to obtain particular score $(0$ becomes 4, 1 becomes 3, 2 stays 2, 3 becomes 1 , and 4 becomes $0)$ the total explained variance of minimum $85 \%$, with minimal reliability shown by the Crombach's coefficient $\alpha$ of 0.7 for each extracted dimension. The accepted level of the statistical significance was 0.05 . To process the data we used the "SPSS 15" (Chicago, IL).

\section{RESULTS}

The study was conducted in 66 healthcare institutions of the Republic of Serbia. Out of 1574 included healthcare professionals, the 102 interviewees were excluded from the study due to the unacceptable number of missing data, so that the total number of healthcare professionals that was analyzed by the structure of the economic reasoning was 1472 .

With CATAPCA model with nine items it resulted in seven-dimensional structure that defined $90.786 \%$ of the total variance (Table 1). Each dimension resulted in high Cronbach's a coefficient (Table 2), while

$\begin{array}{llllllll}\text { Items } & \text { D1 } & \text { D2 } & \text { D3 } & \text { D4 } & \text { D5 } & \text { D6 } & \text { D7 }\end{array}$

(i1) I am familiar with market price of

all alternative interventions (pre-

ventive, diagnostic test, curative or

$\begin{array}{llllllll}.030 & .870 & -.075 & -.065 & -.066 & -.031 & -.003\end{array}$

rehabilitating)

(i2) I am familiar with cost-effectiveness ratio for each alternative considered

$\begin{array}{lllllll}.043 & .861 & -.052 & -.090 & -.136 & -.041 & .055\end{array}$

(i3) It seems to me that I have observed an irrational recommendation of procedures lacking firm evidence on efficiency

(i4) Administration and financial policy in healthcare are considerably involved in the doctor/patient relationship

$\begin{array}{llllll}.772 * & -.058 & -.427 & .015 & -.173 & .066\end{array}$

.068

(i5) Administration and financial policy in healthcare are more focused on cost savings than with the provision of quality health care

(i6) Physicians employed within State owned facilities due to strict inner and outer control, run fewer tests and examinations per patient compared to the physicians employed within privately owned facilities

(i7) The physicians employed within State owned Institutions don 't have the same level of the dedication to the patients as the physicians in the private sector do

(i8) I would avoid prescribing medicines strictly based on instructions of the non-medical management body

(i9) If the patient demands certain laboratory analysis or the imaging examination and the risk of harm is acceptable, the patient should be given the service demanded

$$
\begin{array}{llllll}
.786 * & -.144 & -.381 & -.134 & -.041 & -.058
\end{array}
$$

he total Cronbach's a was 0.988. The HERP-9 Questionnaire and seven highly structurally valid and reliable dimension were obtained. Descriptive statistics for dimension scores and total score are presented in the Table 3.

Calculation of the scores for dimensions and total HPER-9 score obtained by the CATAPCA model (Table 1):
- Dimension 1 score (D1 score) - The negligence of the cost of quality by the administration and financier is expressed as a mean value of the recoded values for the items 4 and 5 : D1 score $=(\mathrm{i} 4$ recoded $+\mathrm{i} 5$ recoded $) / 2$.

- Dimension 2 score (D2 score) - The consideration of the market price and healthcare benefit is expressed as a mean value for the 


\begin{tabular}{|c|c|c|c|}
\hline Dimensions & Cronbach's a & $\%$ of total variance & Total eigenvalue \\
\hline $\begin{array}{l}\text { D1 - The negligence of the cost of quality by the } \\
\text { administration and financier }\end{array}$ & .910 & 9.104 & 20.232 \\
\hline $\begin{array}{l}\text { D2 - The consideration of the market price and } \\
\text { healthcare benefit }\end{array}$ & .893 & 7.880 & 17.511 \\
\hline $\begin{array}{l}\text { D3 - Market orientation considering patient's } \\
\text { requests }\end{array}$ & .850 & 5.918 & 13.150 \\
\hline $\begin{array}{l}\text { D4 - The recognition of inadequate resource alo- } \\
\text { cations by non-medical administrative authority }\end{array}$ & .821 & 5.060 & 11.245 \\
\hline $\begin{array}{l}\text { D5 - The attitude about redirecting the profit } \\
\text { from state to private healthcare sector }\end{array}$ & .808 & 4.758 & 10.574 \\
\hline $\begin{array}{l}\text { D6 - The recognition of the unjustified spending } \\
\text { by the healthcare professionals }\end{array}$ & .780 & 4.210 & 9.356 \\
\hline D7 - The relationship physician / patient & .762 & 3.923 & 8.719 \\
\hline Total & .998 & 90.786 & 40.854 \\
\hline
\end{tabular}

items 1 and 2:

D2 score $=(\mathrm{i} 1+\mathrm{i} 2) / 2$.

- Dimension 3 score (D3 score) - Market orientation considering patient's requests is expressed as mean value for the items 7 and 9: D3 score $=(i 7+i 9) / 2$.

- Dimension 4 score (D4 score) - The recognition of inadequate resource alocations by nonmedical administrative authority is expressed as a mean value for the items 3 and 8 :

D4 score $=(\mathrm{i} 3+\mathrm{i} 8) / 2$

- Dimension 5 score (D5 score) - The attitude about redirecting the profit from state to private healthcare sector is expressed as a mean value of the recoded value for the item 6 and non-recoded value for the item 9:

D5 score $=(\mathrm{i} 6$ recoded $+\mathrm{i} 9) / 2$.

- Dimension 6 score (D6 score) - The recognition of the unjustified spending by the healthcare professionals is expressed as a mean value of the tem 3 and recoded value of the item 8 :

D6 score $=(\mathrm{i} 3+\mathrm{i} 8$ recoded $) / 2$

- Dimension 7 score (D7 score) - The relationship physician/patient is expressed as the value of the item 7:

D7 score $=\mathrm{i} 7$

- The total score of the economic reasoning of health professionals (Total score of the HPER-9), is calculated the following way:

Total score of the HPER-9 $=(\mathrm{i} 1+\mathrm{i} 2+\mathrm{i} 4$ recoded $+\mathrm{i} 5$ recoded $+\mathrm{i} 6 \mathrm{r}$ recoded $+\mathrm{i} 7+\mathrm{i} 8+\mathrm{i} 8$ recoded $+\mathrm{i} 3 \times 2+\mathrm{i} 9 \times 2$ ) .

The minimal value of this score (worst economic reasoning) is 4 (total of i8 and i8 recoded is always 4), and maximal score value (best economic reasoning) is 44 . As this scale has an absolute zero that amounts 4 , while the maximum value is 11 times bigger than the absolute zero, we obtained new continuing scale of the HERP measurement.

The total score can also be expressed as: Total score of the HPER-9 $=(\mathrm{i} 1+\mathrm{i} 2+\mathrm{i} 4 \mathrm{r}$ recoded $+\mathrm{i} 5$ recoded $+\mathrm{i} 6$ recoded $+\mathrm{i} 7+\mathrm{i} 8$ $+\mathrm{i} 8$ recoded $+\mathrm{i} 3 \times 2+\mathrm{i} 9 \times 2)-4$, where the

\begin{tabular}{|c|c|c|c|}
\hline Factor scores of the HPER-9 Questionnaire & $\mathrm{N}$ & Mean & \\
\hline $\begin{array}{l}\text { D1 - The negligence of the cost of quality by the } \\
\text { administration and financier }\end{array}$ & 1472 & 1.46 & .97 \\
\hline $\begin{array}{l}\text { D2 - The consideration of the market price and } \\
\text { healthcare benefit }\end{array}$ & 1472 & 2.76 & .90 \\
\hline $\begin{array}{l}\text { D3 - Market orientation considering patient's } \\
\text { requests }\end{array}$ & 1472 & 1.54 & .90 \\
\hline $\begin{array}{l}\text { D4 - The recognition of inadequate resource alo- } \\
\text { cations by non-medical administrative authority }\end{array}$ & 1472 & 2.49 & .84 \\
\hline $\begin{array}{l}\text { D5 - The attitude about redirecting the profit } \\
\text { from state to private healthcare sector }\end{array}$ & 1472 & 1.91 & .79 \\
\hline $\begin{array}{l}\text { D6 - The recognition of the unjustified spending } \\
\text { by the healthcare professionals }\end{array}$ & 1472 & 2.29 & .74 \\
\hline D7 - The relationship physician / patient & 1472 & 1.49 & 1.22 \\
\hline Total score of the HPER-9 (from 4 to 44 ) & 1472 & 24.91 & 4.38 \\
\hline Total score of the HPER-9 (\%) & 1472 & 52.27 & 10.94 \\
\hline
\end{tabular}

Table 2 . The reliability and the percentage of total explained variance at seventh-dimensional CATAPCA model per dimensions of HPER-9 Questionnaire
Table 3. Descriptive statistics for factor scores and total score of HPER-9 Questionnaire 
minimal score value is 0 , and maximal is 40 .

Total score obtained this way can also be expressed in percentage (\%) as a ratio of the obtained and the maximal score: Total score of the HPER-9 $(\%)=100 \times[(\mathrm{i} 1+\mathrm{i} 2+\mathrm{i} 4$ recoded $+\mathrm{i} 5$ recoded $+\mathrm{i} 6$ recoded $+\mathrm{i} 7+\mathrm{i} 8+\mathrm{i} 8$ recoded $+\mathrm{i} 3 \times 2+\mathrm{i} 9 \times 2)-4] / 40$.

\section{DISCUSSION}

Skootsky et al 1999 defined the assumed HPER structure as the healthcare professionals' attitude for:

1. the concept of providing healthcare and

2. the cost containment policy [8].

However, these authors redefine this beforehead assumed structure fenomenologically and concetually as an important, but not enoguh clarified segment of the physicians' professional satisfaction.

In our earlier studies, the assumed structure of our HPER-29 measurement instrument was defined by dimensios that the healthcare professionals use to express:

1. the attitude towards the choice between the alternatives;

2. the attitude towards the quality of the healthcare and

3. the attitude towards the cost control policy [13].

After the extensive data reduction in this study we have shown that there is a latent, seven-dimensional HPER-9 Questionnaire structure.

The first factor is defined by the level of the agreement with the statements "....administration and financial policy in healthcare are considerably involved in the doctor / patient relationship..." and ,... administration and financial policy in healthcare are more focused on cost savings than with the provision of quality health care...". We named this factor The negligence of the cost of quality by the administration and financier. From the nomenclature and cost quality classification point of view, through the level of the agreement with these items, the healthcare professionals show the level of the cost recognition that are generated by the administration and the financiers while neglecting the healthcare quality in the institutions. In economics, these costs are known as nonconformance cost of quality $[14,15]$. Since the higher level of the cost quality negligence means lower economic healthcare effectivness, answers to these items are recoded in order for scale to get the opposite direction, or, in other words, for the higher score to express less cost quality negligence (better economical heathcare effectiveness). It's interesting that this factor, compared to the others in our seven-dimensional structure, has the highest variance and reliability explained (Table 2). The latter is important, considering that the concept of the healthcare cost quality hasn't been defined yet, which is one of the reasons why they are not shown as extracted items in the regular financial calculations in healthcare institutions [14]. We also highlight that, so far, a small number of studies have been published that contained the subject of the mutual connection of costs and healthcare quality [16-19]. The recognition and the quality cost control is extremely hard and complex job for the management in healthcare institution to do, especially in the conditions where they are limited to do it by the financiers. On the other hand, the effect of the management in the cost quality control is carefully observed by the healthcare professionals in the institution, which makes that the The negligence of the cost of quality the most important HPER factor.

Since the second factor is determined by the items "...I am familiar with market price of all alternative interventions (preventive, diagnostic test, curative or rehabilitating)..." and “...I am familiar with cost-effectiveness ratio for each alternative considered...", this factor is defined as The consideration of the market price and healthcare benefit. It corresponds with making the evidence based practice medical decision, due to which this is a known and very important HPER facor [5].

The third factor is defined by the level of the agreement with the items "...the physicians employed within State owned Institutions don't have the same level of the dedication to the patients as the physicians in the private sector do..." and "... it seems to me that I have observed an irrational recommendation of procedures lacking firm evidence on efficiency..." This factor expresses the significance of the devotion to the patient whose requests need to be considered and acknowledged whenever possible. Since, at the same time, the patient is both the recipient of the healthcare services and the participant in the financing through the health insurance, this factor is named Market orientation considering patient's requests. 
The fourth factor is defined by the level of the agreement with the items "...it seems to me that I have observed an irrational recommendation of procedures lacking firm evidence on efficiency..." and "...I would avoid prescribing medicines strictly based on instructions of the non-medical management body..." This factor expresses the enthusiasm for the healthcare professional to express themselves about the unjustified spending, but also about the bad economic influences of the nonmedical administrative authority due to the lack of or the bad bidirectional communication between the healthcare professionals and the nonmedical administrative authority. That's why we named this factor The recognition of inadequate resource alocations by non-medical administrative authority. The connection establishment of the healthcare administration and management with the healthcare professionals, that encurages the enthusiasm of the healthcare professionals to express themselves about the unjustified spendings in the healthcare institution, lately becomes important in the better developed countries. This becomes important because of the more efficient control and evaluation of the effects of the current economic healthcare reforms in these countries [20]. In other words, by observing this factor there can be considered or even taken the appropriate measures in order to prevent the negative influence of the pharmaceutic corporations to the behaviour of the nonmedical administrative authority, and also of other corporations whose interest is to keep or to enlarge the placement of the products with small net benefits.

The fifth factor is defined by the level of the agreement with the items "...physicians employed within State owned facilities due to strict inner and outer control, run fewer tests and examinations per patient compared to the physicians employed within privately owned facilities..." and "... if the patient demands certain laboratory analysis or the imaging examination and the risk of harm is acceptable, the patient should be given the service demanded..." Since this factor expresses the attitude that the state institutions compared to the private ones cannot make the profit by mostly answering the patients' needs and requests, we named this factor The attitude about redirecting the profit from state to private healthcare sector. Since the item 6 (Table 1) expresses bad economic effects (from the least bad to the most bad), we recoded this answer scale too, so that the scale could have the ascendant character (from the lowest to the highest economic effectiveness). The extraction of this factor is important from the legal and economic point of view, considering that in the United States of America a physician in profit-oriented institutions, when concluding the contract of employment, must accept the clause that after leaving the institution will not conduct the medical practice in the same or a nearby community [21. Since there are clear evidence that this kind of requests are strictly profit-motivated, these clauses were seriously criticized with an explanation that they can potentially harm the patients by limiting their rights to freely chose their physician [22]. The healthcare professionals' observation of the profit redirection from state to private sector can be a significant indicator of the strengthening of the enterprenureal behaviour in private sector, or the shortage of the enterprenureal behaviour in the state sector.

The sixth factor is defined by the level of the agreement with the items "....it seems to me that I have observed an irrational recommendation of procedures lacking firm evidence on efficiency..." and "... I would avoid prescribing medicines strictly based on instructions of the non-medical management body..." This factor, too, expresses the enthusiasm of the healthcare professional to freely express themselves about the unjustified spending that, opposite to the fourth factor, do not come from the nonmedical administrative authority (because the corresponding factorial coefficient has a negative sign - see Table1). We named this factor The recognition of the unjustified spending by the healthcare professionals. Answers to the item 8 are recoded, due to the negative factorial coefficient, so that the scale gets the appropriate (opposite) direction.

Last, the seventh factor is defined by answering one item "...the physicians employed within State owned Institutions don 't have the same level of the dedication to the patients as the physicians in the private sector do..." Since this item highlights only the significance of the devotion to the patient and the significance of the quality of the established relationship between the physician and the patient, we named this factor The relationship physician / patient. This factor expresses the attitude of the healthcare professionals that is shaped by legal, cultural and ethical norms, such as patients' le- 
gal rights, medical ethical code etc. Also, this factor defines the appliability of the previously mentioned regulations as a reflection of the level of the quality culture according to the dimensions of the equity, patient centeredness and the timelines of health service delivery. In our earlier studies, we showed that the patient's satisfaction mostly reflects the achieved levels in two healthcare quality dimensions:

1. patient centeredness of medical staff and

2. the timeliness of health service delivery [23].

\section{CONCLUSION}

Considering the content and the sense of the factors that together explain, sinthesize and that way define the studied phenomenology, we can define the measurement of the Healthcare Professionals' Economic Reasoning as a measurement of the subjectively expressed level of the healthcare professionals' experience of their own economic role, management economic role and the economic role of other healthcare professionals in the institution. Since we extracted the obtained factor with the CATAPCA modeling, this means that the mutual relations between the items in the HPER-9 Questionnaire are not linear and that the specific items will have, by participating in one factor (or dimension), completely different meaning when being a part of any other factor.

\section{ACKNOWLEDGEMENTS}

We would like to express a special gratitude to Samuel A. Skootsky, Stuart Slavin and Michael S. Wilkes from the Office of Education, Development and Research (SAS, MSW), the Division of General Internal Medicine and Health Services Research (SAS, MSW), and the Department of Pediatrics (SS), School of Medicine, University of California, Los Angeles, CA, for kindly providing their consent to use, translate, standardize and validate part of their original questionnaire published in Am J Manag Care 1999;5:1397-1404., in an academic non sponsored cross-sectional survey study.

The authors would also like to express their gratitude to the Ministry of Education, Science and Technological Development of the Republic of Serbia, for Grant [OI N ${ }^{\circ} 175014$ ] out of which this trial was funded.
We are also thankful for lingustic corrections of this text to Ana Vuković, language and literature professor.

\section{REFERENCES}

1. Fisher ES, Bynum JP, Skinner JS. Slowing the growth of health care costs-lessons from regional variation. N Engl J Med 2009;360(9):849-52.

2. Council on Ethical and Judicial Affairs. Physician stewardship of health care resources. available at: http: //www.ama-assn.org/resources/doc/ethics/ ceja-1a12.pdf. Accesed December 10, 2015.

3. Centers for Medicare \& Medicaid Services, Office of the Actuary, National Health Statistics Group; and U.S. Department of Commerce, Bureau of Economic Analysis and Bureau of the Census. National Health Expenditure Data: Historical, 2009.

4. Yasaitis L, Fisher ES, Skinner JS, Chandra A. Hospital quality and intensity of spending: is there an association? Health Aff (Millwood) 2009;28(4):w56672.

5. Kocher R, Emanuel EJ, DeParle NA. The Affordable Care Act and the future of clinical medicine: the opportunities and challenges. Ann Intern Med 2010;153(8):536-39.

6. Hurst SA, Slowther AM, Forde R, et al. Prevalence and determinants of physician bedside rationing: data from Europe. J Gen Intern Med 2006;21(11):1138-43.

7. Goold SD, Hofer T, Zimmerman M, Hayward RA. Measuring physician attitudes toward cost, uncertainty, malpractice, and utilization review. J Gen Intern Med 1994;9(10):544-49.

8. Skootsky AS, Slavin S, Wilkes MS. Attitudes Toward Managed Care and Cost Containment Among Primary Care Trainees at 3 Training Sites. Am J Manag Care 1999;5:1397-404.

9. Palmer D. Tackling Malawi's human resources crisis. Reproductive Health Matters 2006;14:27-39.

10. Schoo AM, Stagniti KE, Mercer C, Dunbar J. A conceptual model for recruitment and retention: allied health workforce enhancement in Western Victoria, Australia. Rural and Remote Health 2005; 5(4):477:233-48.

11. Cuckler GA, Sisko AM, Keehan SP, Smith SD, Madison A, Poisal JA, et al. National Health Expenditure Projections, 2012-22: Slow Growth Until Coverage Expands And Economy Improves. Health Affairs 2013;32:1820-31.

12. Buckley P. The United States: Working toward a recovery that can stand on its own. Global Economic Outlook 3rd Quarter 2013 Deloitte University Press, 2013.

13. Jakovljevic $M$, Vukovic $M$, Chen $C$, et al. Do Health Reforms Impact Cost Consciousness of Health 
Care Professionals? Results from a Nation-Wide Survey in the Balkans. Balkan Medical Journal 2015; in press. DOI:10.5152/balkanmedj.2015.15869

14. Bony P, Krishnamoorthy KS. Applying Cost of Quality in Health Care. Proceedings of the 17th Annual Society for Health Systems Management Engineering Forum, Dallas, TX, 2005.

15. Feigenbaum AV. Total Quality Control (3 ed.), New York, New York 1991: McGraw-Hill:111.

16. Hussey PS, Wertheimer S, Mehrotra A. The association between health care quality and cost: A systematic review. Ann Intern Med 2005;158(1):27-34.

17. Kabene SM, Orchard C, Howard JM, Soriano MA, Leduc $R$. The importance of human resources management in health care: a global context. Human Resources for Health 2006;4:20. doi:10.1186/14784491-4-20.

18. Williams SC, Schmaltz SP, Morton DJ, Koss RG, Loeb JM. Quality of care in U.S. hospitals as reflected by standardized measures, 2002-2004. N Engl J Med 2005; 353:255-64.

19. Chassin MR, Galvin RW. The urgent need to improve health care quality: Institute of Medicine National Roundtable on Health Care Quality. JAMA1998; 280:1000-5.

20. Tilburt JC, Wynia MK, Sheeler RD, Thorsteinsdottir B, James KM, Egginton JS, Liebow M, Hurst S, Danis M, Goold SD. Views of US Physicians About Controlling Health Care Costs. JAMA 2013;310(4):380-8. doi:10.1001/jama.2013.8278

21. Kinney ED. The Corporate Transformation of Medical Specialty Care: The Exemplary Case of Neonatology. J Law Med Ethics 2008;36(4):790-802.

22. Wilbom Malloy SE. Physician Restrictive Covenants: The Neglect of Incumbent Patient Interests. Wake Forest L Rev 2006;41:189.

23. Vuković M, Grozdenović BS, Gajić T, Stamatović Gajić B, Jakovljević M, McCormick BP. Validation of a patient satisfaction questionnaire in primary health care. Public Health 2012:126(8):710-18. 


\title{
Strukturna validnost i relijabilnost upitnika ekonomskog rasuđivanja zdravstvenih stručnjaka
}

\author{
Mira H. Vuković ${ }^{1}$, Mihajlo B. Jakovljević ${ }^{2}$ \\ ${ }^{1}$ Centar za edukaciju, Opšta bolnica Valjevo, Valjevo, Serbia \\ ${ }^{2}$ Zdravstvena ekonomija i Farmakoekonomija, Fakultet medicinskih nauka Univerziteta u Kragujevcu, \\ Kragujevac, Srbija
}

\section{KRATAK SADRŽAJ}

Uvod: Struktura ekonomskog rasuđivanja zdravstvenih stručnjaka (ERZS) još uvek nije poznata.

Cij rada: Procenjena je konstrukciona validnost i pouzdanost upitnika ERZS.

Metod: Sprovedena je psihometrijska studija procene činilaca ERZS. Anketirani su zdravstveni stručnjaci (lekari, stomatolozi, farmaceuti) zaposleni u državnom sektoru zdravstva Republike Srbije. Upitnik ERHP sačinjen je od preliminarnih 29 pitanja. Struktura ERZS upitnika ispitana je analizom glavnih komponenti za kategorijske i ordinalne podatke.

Rezultati: Ekstrahovano je 9 pitanja sa kojima je definisano sedam faktora ERZS: (1) zanemarivanje troškova kvaliteta od strane administracije i finansijera; (2) razmatranje tržišne cene i zdravstvene dobiti; (3) tržišna orijentisanost u pogledu zahteva pacijenta; (4) prepoznavanje neadekvatne alokacije sredstava od strane nemedicinskih organa uprave; (5) stav o preusmeravanju profita iz državnog u privatni sektor zdravstva; (6) prepoznavanje neopravdane potrošnje od strane zdravstvenih profesionalaca i (7) odnos lekar / pacijent.

Zaključak: Upitnik ERHP-9 ima visoku validnost i relijabilnost u merenju ERZS.

Ključne reči: ekonomsko rasuđivanje, zdravstveni profesionalci, zdravstvene ustanove, psihometrijska analiza 